\title{
ANALISA KONDISI LAHAN PARKIR RAMAYANA MALL SORONG
}

\author{
Serly Marlina ${ }^{1)}$ Lilis Fitri Handayani ${ }^{2)}$ Agus Sukrisman ${ }^{3)}$ \\ ${ }^{1), 2)}$ Program Studi Teknik Sipil Universitas Muhammadiyah Sorong \\ Jalan Pendidikan No 27 Kota Sorong, Propinsi Papua Barat \\ Email : serlymarlina723@gmail.com
}

\begin{abstract}
ABSTRAK
Parkir merupakan tempat pemberhentian kendaraan di suatu kawasan atau bangunan, dimana masyarakat melakukan berbagai aktivitas. Permasalahan seperti kebutuhan ruang parkir yang melebihi kapasitas dapat terjadi, karena pusat perbelanjaan memiliki tingkat aktivitas perekonomian yang cukup tinggi sehingga kebutuhan ruang parkir juga tinggi. Tujuan dari pengamatan ini adalah untuk mendapatkan data durasi parkir kendaraan roda empat yang berada di mall Ramayana Sorong. Metode penelitian yang digunakan adalah dengan melakukan pengamatan secara langsung terhadap area parkir Ramayana Mall Sorong. Kesimpulan yang dihasilkan adalah : 1) Dalam pengamatan yang telah dilakukan kurang lebih selama 2 jam terdapat 30 kendaraan yang belum diketahui waktu keluarnya kendaraan tersebut.2)Dari hasil pengamatan yang telah dilakukan didapat 5 kendaraan yang memiliki durasi parkir kurang dari 2 jam dan 25 kendaraan yang memiliki durasi parkir kuarng dari 1 jam.3)Rata - rata durasi parkir kendaraan roda empat yang dikendarai oleh pria yaitu 39 menit 74 detik.4)Rata - rata durasi parkir kendaraan roda empat yang dikendarai oleh wanita yaitu 45 menit 50 detik.5)Rata - rata durasi parkir kendaraan roda empat yang memiliki penumpang pria dan wanita yaitu 47 menit 15 detik.
\end{abstract}

Kata Kunci : area,parkir,Ramayana mall

\section{PENDAHULUAN}

Parkir merupakan tempat pemberhentian kendaraan di suatu kawasan atau bangunan, dimana masyarakat melakukan berbagai aktivitas. Pusat aktivitas masyarakat dapat berupa di kawasan pusat perbelanjaan. Daya tarik kawasan dengan tingkat mobilitas barang dan manusia yang tinggi, menciptakan pergerakan lalu lintas yang padat di kawasan. Akibatnya, terjadi peningkatan kebutuhan ruang parkir di kawasan komersial ini. Pengetahuan tentang ruang parkir di pusat perbelanjaan yang berfungsi sebagai referensi perencanaaan ruang parkir yang baik di kawasan dan bangunan sangat diperlukan.

Permasalahan seperti kebutuhan ruang parkir yang melebihi kapasitas dapat terjadi, karena pusat perbelanjaan memiliki tingkat aktivitas perekonomian yang cukup tinggi sehingga kebutuhan ruang parkir juga tinggi. Selain itu, harga lahan yang mahal dan luas lahan yang sempit, membuat bangunan pusat perbelanjaan memiliki keterbatasan lahan, sehingga lahan yang diperuntukan bagi ruang parkir tidak menjadi prioritas utama. 
Tujuan dari pengamatan ini adalah untuk mendapatkan data durasi parkir kendaraan roda empat yang berada di mall Ramayana Sorong. Metode penelitian yang digunakan adalah dengan melakukan pengamatan secara langsung terhadap area parkir Ramayana Mall Sorong.

\section{METODOLOGI}

Hari / Tanggal : Minggu / 03 Juni 2018

Lokasi : Ramayana Mall

Cuaca : Mendung

Waktu $\quad: 16.00-18.00$ WIT

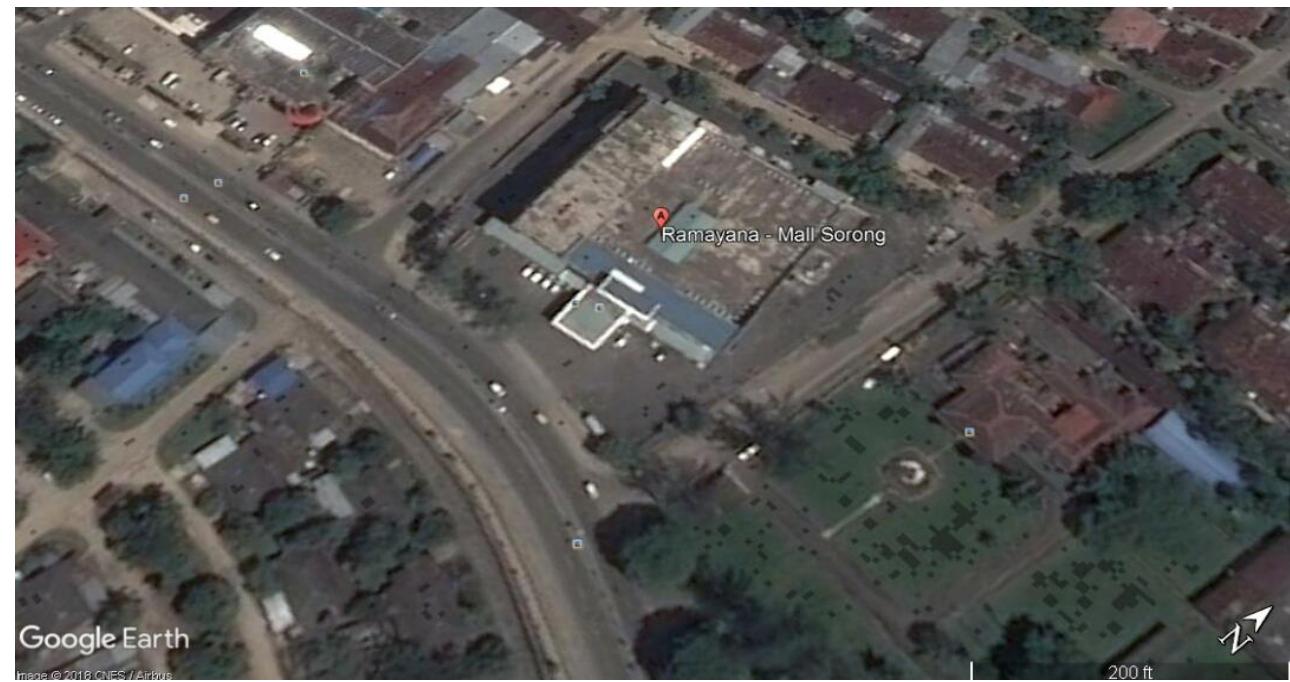

Gambar Lokasi Ramayana Mall Sorong

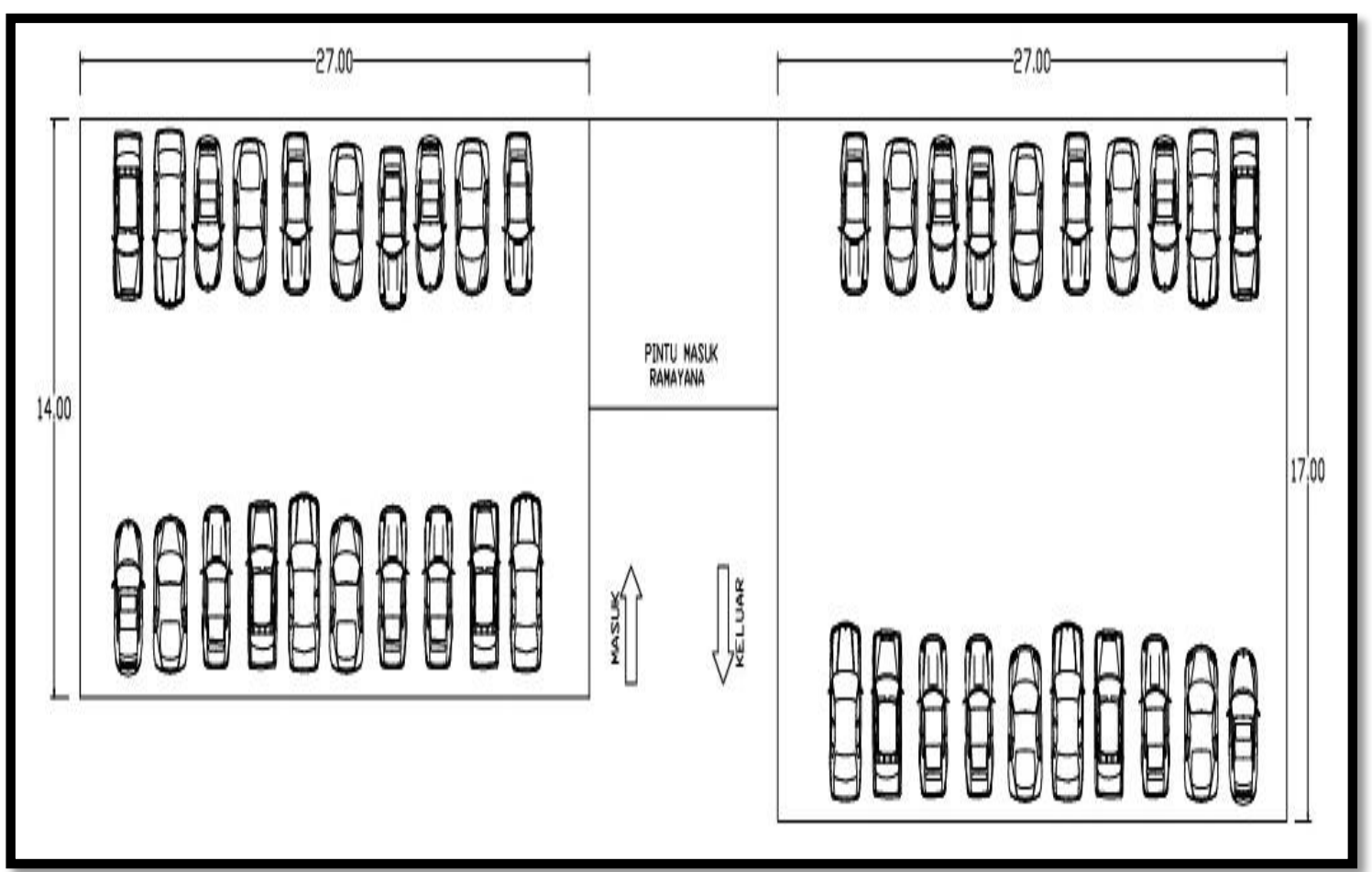

Gambar Lokasi Area Parkir 
Tahapan penyusunan artikel:

1. Menentukan tema

2. Pengambilan data di lokasi study

3. Analisa data

4. Membuat kesimpulan untuk menjawab tujuan penulisan artikel.

Semua metode penulisan dan analisa dalam artikel ilmiah ini merujuk pada panduan penulisan tugas akhir Fakultas Teknik Universitas Muhammadiyah Sorong tahun 2014 (Pristianto, Amri \& Rusdi,2018 ).

\section{HASIL DAN PEMBAHASAN}

\begin{tabular}{|c|c|c|c|c|}
\hline \multirow{2}{*}{ No } & \multirow{2}{*}{ No Kendaraan } & \multicolumn{2}{|c|}{ Waktu Kendaraan Parkir } & \multirow{2}{*}{$\begin{array}{c}\text { Jenis Kelamin Penumpang } \\
\text { Pria / Wanita / PW }\end{array}$} \\
\hline & & Masuk & Keluar & \\
\hline 1 & PB $7370 \mathrm{SH}$ & 16.00 & & PW \\
\hline 2 & PB 1673 SI & 16.02 & 16.51 & Pria \\
\hline 3 & PB 1967 SB & 16.04 & 16.36 & Pria \\
\hline 4 & PB 1978 SL & 16.04 & 16.23 & Pria \\
\hline 5 & PB $1455 \mathrm{SL}$ & 16.05 & 17.41 & Pria \\
\hline 6 & PB 1782 SK & 16.05 & 17.12 & Pria \\
\hline 7 & PB $1678 \mathrm{SO}$ & 16.07 & & Pria \\
\hline 8 & PB 1943 SK & 16.14 & 17.18 & PW \\
\hline 9 & PB $1632 \mathrm{R}$ & 16.15 & 17.46 & PW \\
\hline 10 & PB $1693 \mathrm{SH}$ & 16.16 & 17.28 & $\mathrm{PW}$ \\
\hline 11 & PB $1604 \mathrm{~T}$ & 16.16 & 16.43 & Pria \\
\hline 12 & PB 1302 SR & 16.18 & & Pria \\
\hline 13 & PB 1661 AZ & 16.19 & 16.50 & Pria \\
\hline 14 & PB $1733 \mathrm{SH}$ & 16.20 & 16.47 & Pria \\
\hline 15 & PB $1925 \mathrm{SE}$ & 16.21 & 17.05 & Pria \\
\hline 16 & PB $1652 \mathrm{SH}$ & 16.22 & 17.37 & Pria \\
\hline 17 & PB 1648 SC & 16.23 & 17.34 & Pria \\
\hline 18 & PB 1974 SJ & 16.28 & 17.18 & PW \\
\hline 19 & PB $1513 \mathrm{SC}$ & 16.29 & 16.58 & PW \\
\hline 20 & PB $1697 \mathrm{SA}$ & 16.36 & 17.39 & $\mathrm{PW}$ \\
\hline 21 & PB $5974 \mathrm{~S}$ & 16.38 & 17.23 & PW \\
\hline 22 & PB 1598 SJ & 16.39 & 17.28 & $\mathrm{PW}$ \\
\hline 23 & PB $1570 \mathrm{SH}$ & 16.46 & 17.07 & Pria \\
\hline 24 & PB 1840 SI & 16.46 & 17.57 & Pria \\
\hline 25 & PB $5813 \mathrm{SL}$ & 16.48 & 17.20 & Pria \\
\hline 26 & PB $1863 \mathrm{~S}$ & 16.48 & 17.57 & Wanita \\
\hline 27 & PB $4069 \mathrm{SH}$ & 16.50 & & Pria \\
\hline 28 & PB 1683 SJ & 16.51 & & Pria \\
\hline 29 & PB 1745 SW & 16.52 & 17.07 & $\mathrm{PW}$ \\
\hline 30 & B 1079 PDV & 16.54 & & Pria \\
\hline
\end{tabular}




\begin{tabular}{|c|c|c|c|c|}
\hline \multirow{2}{*}{ No } & \multirow{2}{*}{ No Kendaraan } & \multicolumn{2}{|c|}{ Waktu Kendaraan Parkir } & \multirow{2}{*}{$\begin{array}{c}\text { Jenis Kelamin Penumpang } \\
\text { Pria / Wanita / PW }\end{array}$} \\
\hline & & Masuk & Keluar & \\
\hline 31 & DB $1231 \mathrm{LF}$ & 16.56 & 17.24 & Pria \\
\hline 32 & PB $1701 \mathrm{SS}$ & 16.57 & 17.34 & $\mathrm{PW}$ \\
\hline 33 & B 1359 KIR & 17.02 & 17.23 & Pria \\
\hline 34 & PB $1641 \mathrm{SW}$ & 17.04 & 17.29 & Pria \\
\hline 35 & PB 1573 SW & 17.04 & 17.42 & Pria \\
\hline 36 & PB 1375 SGY & 17.05 & 17.49 & Pria \\
\hline 37 & PB 1613 A & 17.06 & 17.49 & Pria \\
\hline 38 & B 1835 UIN & 17.06 & 17.28 & Wanita \\
\hline 39 & B 1375 SGY & 17.06 & 17.49 & PW \\
\hline 40 & PB $1935 \mathrm{SE}$ & 17.07 & 17.15 & Pria \\
\hline 41 & PB 1742 SJ & 17.08 & & Pria \\
\hline 42 & PB $8589 \mathrm{~S}$ & 17.09 & 17.22 & Pria \\
\hline 43 & PB $1555 \mathrm{SL}$ & 17.14 & 17.33 & $\mathrm{PW}$ \\
\hline 44 & PB 1516 SW & 17.16 & 17.52 & $\mathrm{PW}$ \\
\hline 45 & L 9647 VZ & 17.16 & & Pria \\
\hline 46 & DD $1265 \mathrm{CD}$ & 17.18 & & Pria \\
\hline 47 & PB $1265 \mathrm{CD}$ & 17.18 & & Pria \\
\hline 48 & B 2253 TOO & 17.19 & 17.51 & Pria \\
\hline 49 & PB1884 SF & 17.21 & & PW \\
\hline 50 & PB 1954 SG & 17.23 & & $\mathrm{PW}$ \\
\hline 51 & PB $1590 \mathrm{SG}$ & 17.24 & & $\mathrm{PW}$ \\
\hline 52 & PB $8710 \mathrm{SL}$ & 17.25 & & Pria \\
\hline 53 & PB 8022 SC & 17.30 & & Pria \\
\hline 54 & PB $1909 \mathrm{SE}$ & 17.31 & & $\mathrm{PW}$ \\
\hline 55 & BE 1 UN & 17.32 & & PW \\
\hline 56 & BE $1451 \mathrm{RC}$ & 17.36 & & pria \\
\hline 57 & PB $1451 \mathrm{RC}$ & 17.37 & & PW \\
\hline 58 & BE 1434 RC & 17.39 & & Wanita \\
\hline 59 & PB 8819 A & 17.39 & & Pria \\
\hline 60 & PB 1510 A & 17.39 & & Pria \\
\hline 61 & PB $1592 \mathrm{SH}$ & 17.42 & & Pria \\
\hline 62 & PB 1982 SA & 17.43 & & Pria \\
\hline 63 & PB $1653 \mathrm{SN}$ & 17.43 & & PW \\
\hline 64 & PB $1794 \mathrm{~S}$ & 17.49 & & Pria \\
\hline 65 & PB 1612 SB & 17.49 & & Pria \\
\hline 66 & DD $1401 \mathrm{UI}$ & 17.50 & & PW \\
\hline 67 & L 1658 CE & 17.51 & & PW \\
\hline 68 & PB 1980 SJ & 17.56 & & Pria \\
\hline 69 & PB 1599 SB & 17.58 & & $\mathrm{PW}$ \\
\hline
\end{tabular}


Berdasarkan pengamatan yang telah kami lakukan pada hari minggu tanggal 03 juni 2018 di Ramayana Mall Sorong. Didapat hasil seperti tabel diatas , yang mana terdapat hanya 69 kendaraan roda empat yang parkir.Yang pertama terdapat 42 mobil yang di kendarai oleh pria. Yang kedua hanya terdapat 3 mobil yang di kendarai oleh wanita.Dan yang ketiga terdapat 24 mobil yang di tumpangi oleh pria dan wanita .

\begin{tabular}{|c|c|}
\hline \multicolumn{2}{|c|}{ Durasi Parkir Kendaraan Roda Empat } \\
\hline Penumpang Pria & Waktu \\
\hline 1 & 49 \\
\hline 2 & 32 \\
\hline 3 & 19 \\
\hline 4 & 96 \\
\hline 5 & 67 \\
\hline 6 & 27 \\
\hline 7 & 31 \\
\hline 8 & 27 \\
\hline 9 & 44 \\
\hline 10 & 75 \\
\hline 11 & 71 \\
\hline 12 & 21 \\
\hline 13 & 71 \\
\hline 14 & 32 \\
\hline 15 & 28 \\
\hline 16 & 21 \\
\hline 17 & 25 \\
\hline 18 & 38 \\
\hline 19 & 44 \\
\hline 20 & 43 \\
\hline 21 & 8 \\
\hline 22 & 13 \\
\hline 23 & 32 \\
\hline Jumlah & 914 \\
\hline Rata - Rata & 39,74 \\
\hline
\end{tabular}




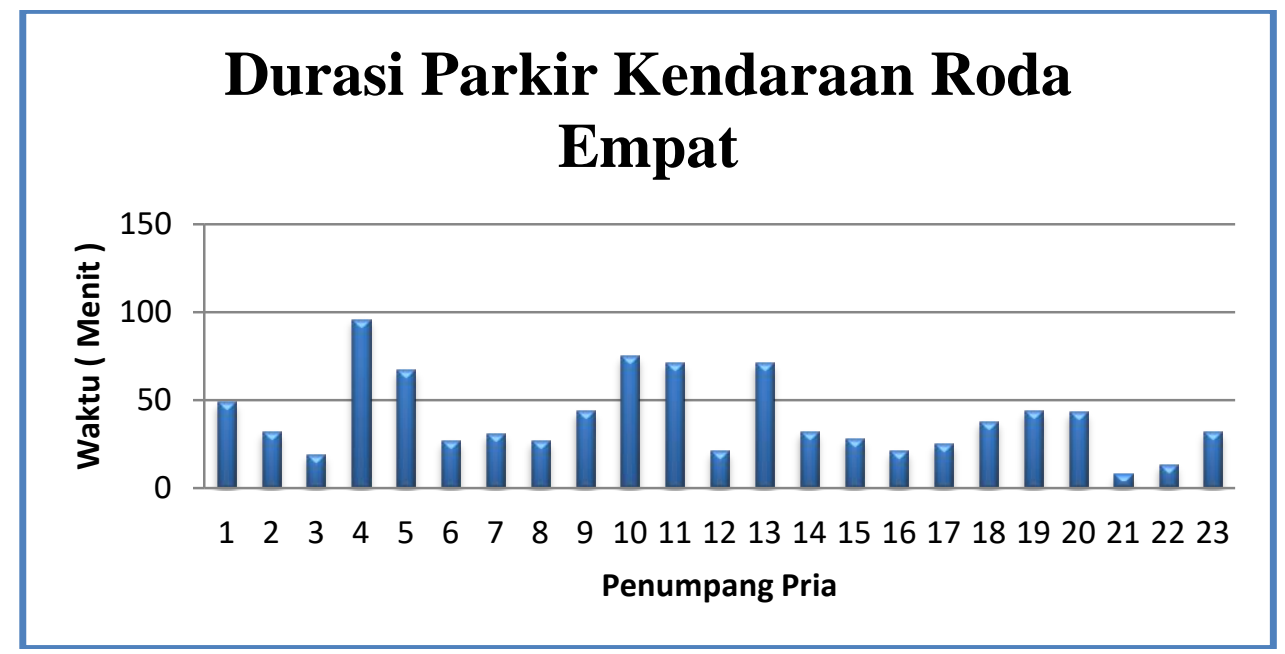

Berdasarakan tabel dan diagram diatas diketahui bahwa durasi parkir kendaraan roda empat yang di kendarai oleh pria rata-rata memiliki durasi parkir selama 39 menit 74 detik.

\begin{tabular}{|c|c|}
\hline \multicolumn{2}{|c|}{ Durasi Parkir Kendaraan Roda Empat } \\
\hline Penumpang Wanita & Waktu \\
\hline 1 & 69 \\
\hline 2 & 22 \\
\hline & \\
\hline Jumlah & 91 \\
\hline Rata - Rata & $\mathbf{4 5 , 5 0}$ \\
\hline
\end{tabular}

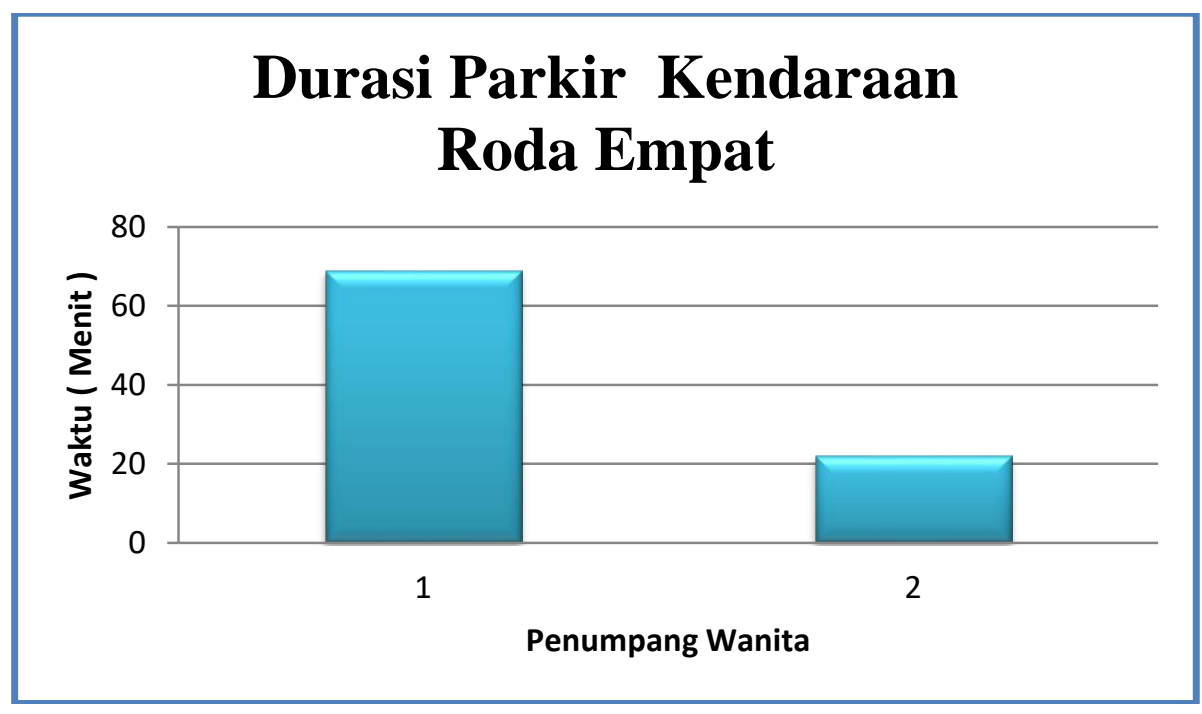

Berdasarakan tabel dan diagram diatas diketahui bahwa durasi parkir kendaraan roda empat yang di kendarai oleh wanita rata-rata memiliki durasi parkir selama 45 menit 50 detik. 


\begin{tabular}{|c|c|}
\hline \multicolumn{2}{|c|}{ Durasi Parkir Kendaraan Roda Empat } \\
\hline Penumpang Pria + Wanita & Waktu \\
\hline 1 & 64 \\
\hline 2 & 91 \\
\hline 3 & 72 \\
\hline 4 & 50 \\
\hline 5 & 29 \\
\hline 6 & 63 \\
\hline 7 & 45 \\
\hline 8 & 49 \\
\hline 9 & 15 \\
\hline 10 & 37 \\
\hline 11 & 43 \\
\hline 12 & 19 \\
\hline 13 & 36 \\
\hline Jumlah & 613 \\
\hline Rata - Rata & 47,15 \\
\hline
\end{tabular}

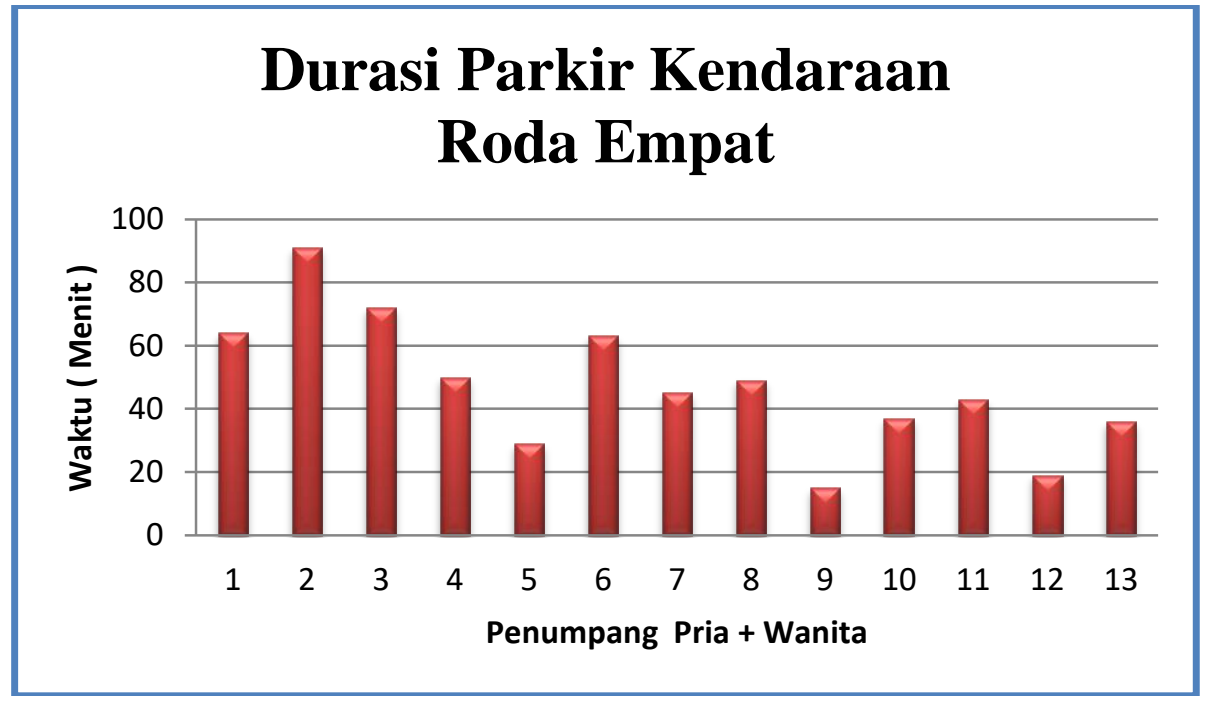

Berdasarakan tabel dan diagram diatas diketahui bahwa durasi parkir kendaraan roda empat yang di tumpangi oleh pria dan wanita rata-rata memiliki durasi parkir selama 47 menit 15 detik. 


\begin{tabular}{|c|l|c|}
\hline No & Penumpang Mobil & Rata - Rata Durasi Parkir \\
\hline 1 & Pria & 39,74 \\
\hline 2 & Wanita & 45,5 \\
\hline 3 & Pria + Wanita & 47,15 \\
\hline
\end{tabular}

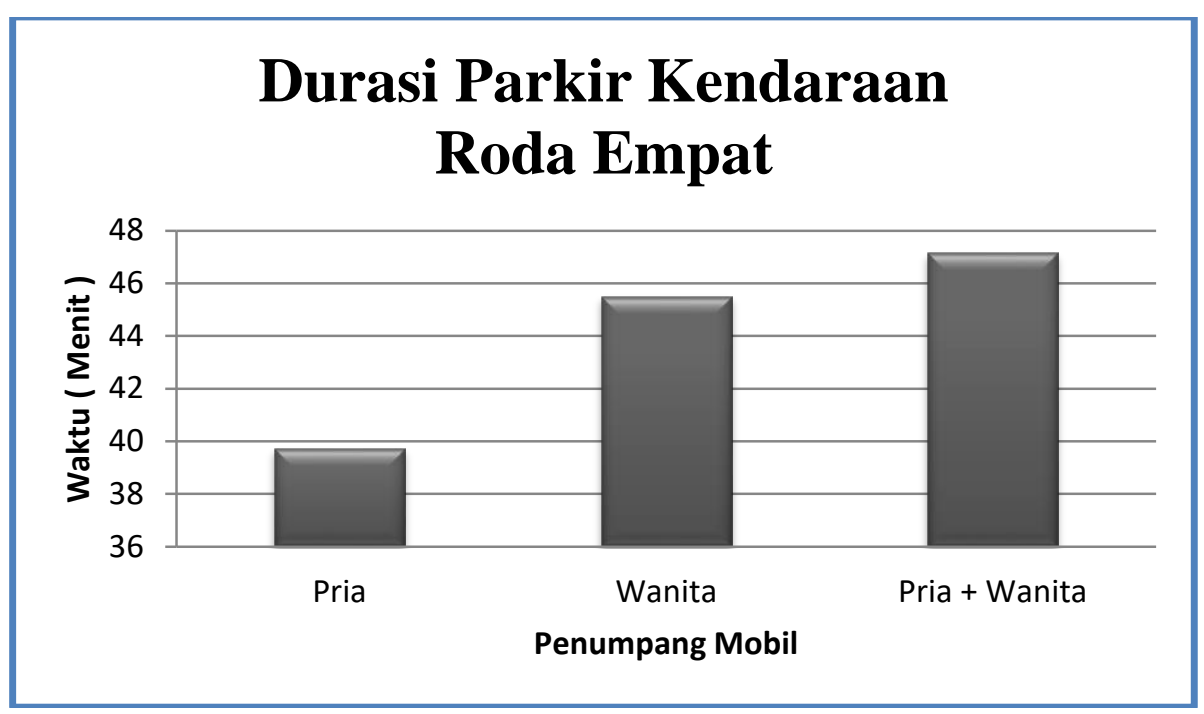

Berdasarakan tabel dan diagram diatas diketahui bahwa durasi parkir kendaraan roda empat yang di kendarai oleh pria rata-rata memiliki durasi parkir selama 39 menit 74 detik. Durasi parkir kendaraan roda empat yang di kendarai oleh wanita rata-rata memiliki durasi parkir selama 45 menit 50 detik.Sedangkan durasi parkir kendaraan roda empat yang di tumpangi oleh pria dan wanita rata-rata memiliki durasi parkir selama 47 menit 15 detik.

\section{DOKUMENTASI}
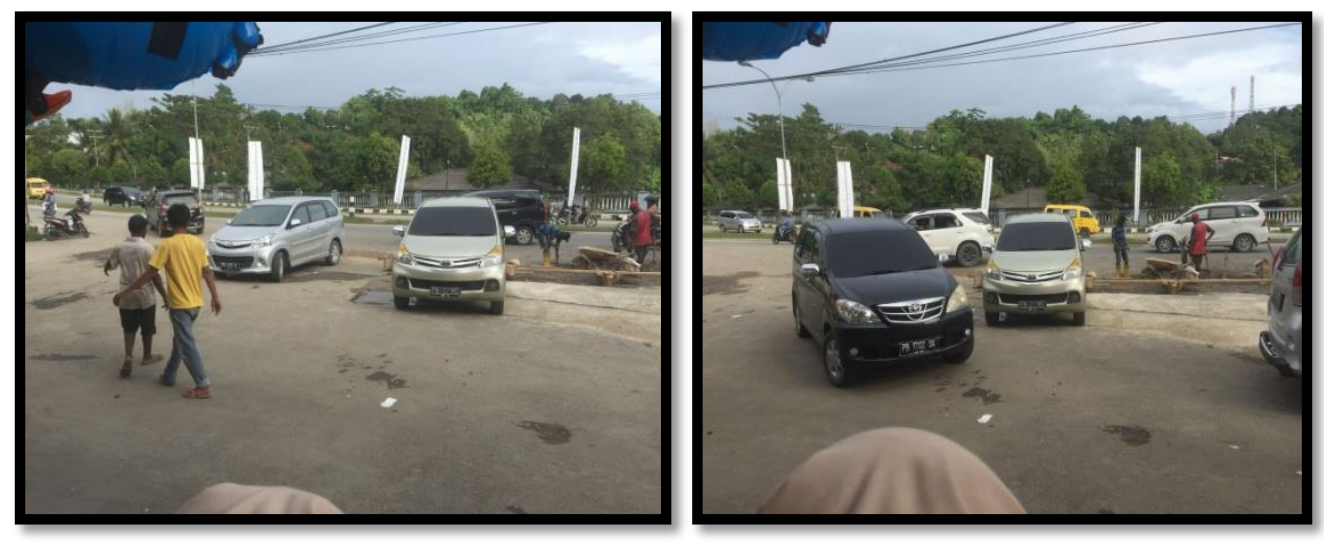

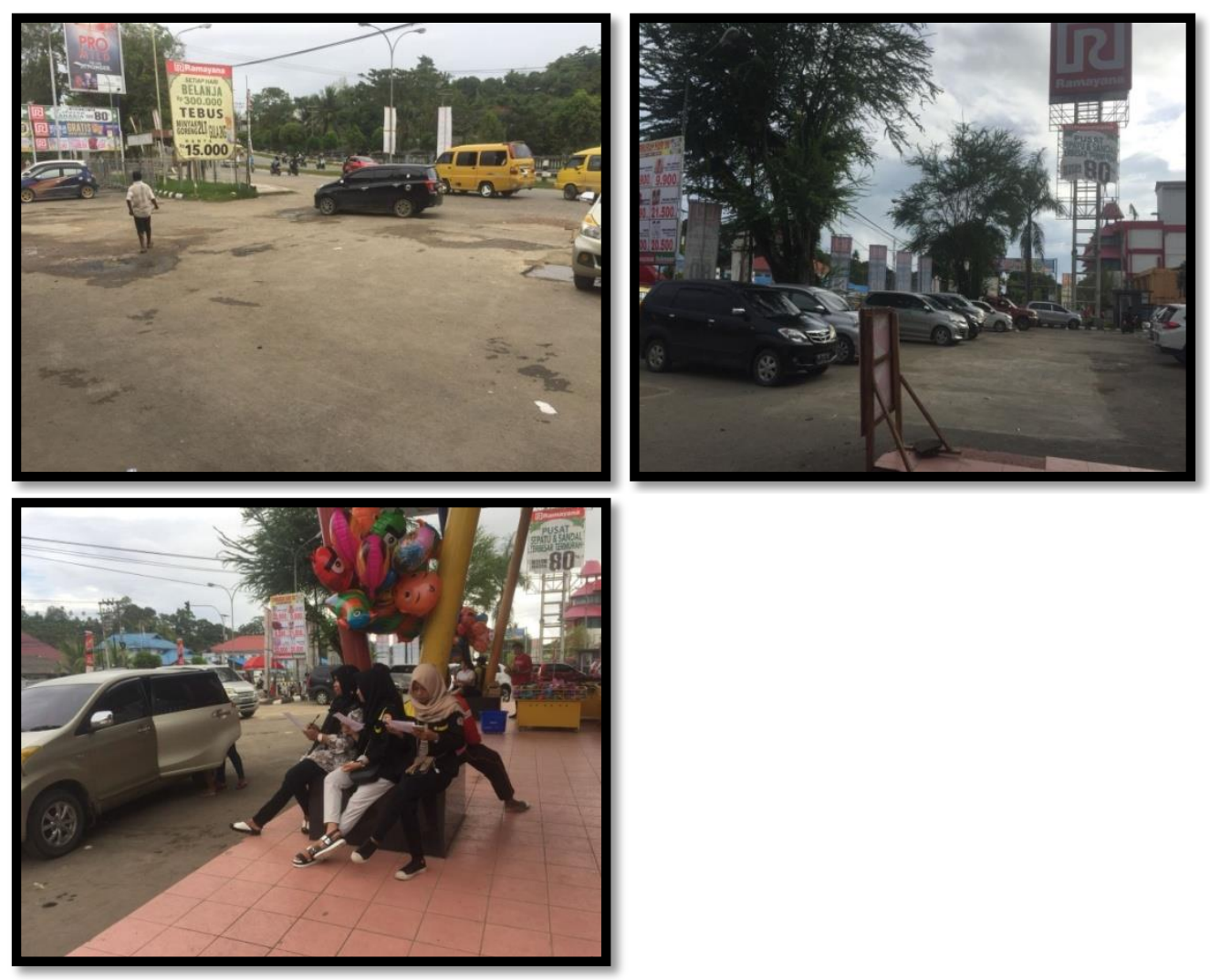

Gambar diatas menujukkan suasana area parkir Ramayana Mall Sorong pada hari minggu tanggal 03 juni 2018 pukul $16.00-18.00$ wit.

\section{KESIMPULAN}

Berdasarkan dari data hasil pengamatan durasi parkir kendaraan roda 4 yang telah di lakukan di Ramayana Mall Sorong pada jam 16.00 - 18.00 WIT dalam keadaan cuaca mendung dapat di simpulkan bahwa :

1. Dalam pengamatan yang telah dilakukan kurang lebih selama 2 jam hanya terdapat 69 kendaraan roda empat.

2. Dari hasil pengamatan yang telah dilakukan kurang lebih selama 2 jam terdapat 30 kendaraan yang belum diketahui kapan waktu keluarnya kendaraan tersebut.

3. Dari hasil pengamatan yang telah dilakukan didapat 5 kendaraan yang memiliki durasi parkir kurang dari 2 jam dan 25 kendaraan yang memiliki durasi parkir kuarng dari 1 jam.

4. Rata - rata durasi parkir kendaraan roda empat yang dikendarai oleh pria yaitu 39 menit 74 detik.

5. Rata - rata durasi parkir kendaraan roda empat yang dikendarai oleh wanita yaitu 45 menit 50 detik.

6. Rata - rata durasi parkir kendaraan roda empat yang memiliki penumpang pria dan wanita yaitu 47 menit 15 detik. 


\section{DAFTAR PUSTAKA}

1. Repositori.ump.ac.id

2. https://www.researchgate.net

3. erepo.unud.ac.id

4. Data dari hasil survey / pengamatan yang dilakukan.

5. Pristianto, H., Amri, I., \& Rusdi, A. (2018). Pedoman Penulisan Tugas Akhir Fakultas Teknik Universitas Muhammadiyah Sorong. 